\title{
Statistics and Computational Fluid Dynamics Analyses of the Experimentally Confirmed Thermal Behavior of Self-designed Internally Cooled Smart Cutting Tool
}

Erkan Öztürk ( $\nabla$ erkan.ozturk@omu.edu.tr)

Ondokuz Mayis Universitesi

Kemal Yıldızı

Ondokuz Mayis Universitesi

Original Research

Keywords: Internally cooled, cutting tool, CFD, Taguchi method, sustainable

Posted Date: February 4th, 2021

DOI: https://doi.org/10.21203/rs.3.rs-162113/v1

License: (c) (1) This work is licensed under a Creative Commons Attribution 4.0 International License.

Read Full License 


\title{
Statistics and Computational Fluid Dynamics Analyses of the Experimentally Confirmed Thermal Behavior of Self-designed Internally Cooled Smart Cutting Tool
}

\author{
Erkan Öztürk ${ }^{1 *}$, Kemal Yıldızlı ${ }^{1}$ \\ 1) Department of Mechanical Engineering, Faculty of Engineering, \\ Ondokuz Mayıs University, 55200 Atakum, Samsun, Turkey \\ $1^{*}$ erkan.ozturk@omu.edu.tr (Corresponding Author) Tel: +90 36231219 19-1322 \\ ${ }^{1}$ kyildizli@omu.edu.tr
}

\begin{abstract}
When compared with dry machining, using traditional cutting fluids has some weaknesses such as environmental pollution, high machining costs and harmful effects on human health. Internally cooled cutting tools (ICCT) have been a promising, sustainable, health-friendly and green technologies for turning applications. However, the effects of different types of internal coolant fluids on insert tip temperature $\left(\mathrm{T}_{\text {tip }}\right)$ have not been investigated for ICCTs. Within effective cooling, machining quality of metallic materials and tool life can improve. Therefore, a conjugate heat transfer (CHT) model for a self-designed internally cooled smart cutting tool (ICSCT) was set. The CHT simulation was experimentally confirmed using pure water. After that, the effects of flow velocity $\left(\mathrm{V}_{\mathrm{f}}\right)$, inlet temperature of the coolant fluid ( $\left.\mathrm{T}_{\text {inlet}}\right)$ alongside different types of glycol-based heat transfer fluids (including pure water) on $\mathrm{T}_{\text {tip }}$ were statistically evaluated by the Taguchi method and analysis of the variance (ANOVA). It was found that the most effective factor was the $\mathrm{T}_{\text {inlet }}$ at a contribution ratio level of $88.32 \%$. Additionally, $\mathrm{V}_{\mathrm{f}}$ and the type of heat transfer fluid were found to be significant according to statistics. Hence, since no external coolant is used, the designed smart tool can be counted as being environmentally friendly and health friendly. In conclusion, the glycol-based fluids can be a better choice for internally cooled tool designs owing to their superior features, e.g., corrosion prevention, nontoxicity and stable heat transfer capability at lower temperatures compared to pure water although pure water has better thermal properties than the glycol-based fluids.
\end{abstract}

Keywords: Internally cooled, cutting tool, CFD, Taguchi method, sustainable

\section{Nomenclatures}

\section{a. Abbreviations}

CFD : Computational fluid dynamics

CHT : Conjugate heat transfer 
FEM : Finite Element Method

ICCT : Internally cooled cutting tool

MQL : Minimum quantity lubrication

PCR : Percentage contribution ratio

ICSCT : Internally cooled smart cutting tool

\section{b. Symbols}

n : The number of experiments

$\mathrm{S} / \mathrm{N} \quad$ : Signal-to-noise ratio

$S^{2} \quad:$ The variance for the observed data

$\mathrm{T}_{\mathrm{f}} \quad$ : Flank surface temperature of insert $\left({ }^{\circ} \mathrm{C}\right)$

Tinlet : Inlet temperature of the coolant fluid $\left({ }^{\circ} \mathrm{C}\right)$

$\mathrm{T}_{\text {tip }} \quad$ : Tip temperature of the insert $\left({ }^{\circ} \mathrm{C}\right)$

$T_{\text {tip }}$ :al The calculated $\mathrm{T}_{\text {tip }}$ value

$\mathrm{V}_{\mathrm{f}} \quad$ : Flow velocity $(\mathrm{m} / \mathrm{s})$

$\mathrm{yi}_{\mathrm{i}} \quad$ : The observed data in the experiments

$\bar{y} \quad:$ The mean for the observed data in the experiments

$\overline{A_{0}} \quad:$ The average $\mathrm{S} / \mathrm{N}$ ratios when the factor $\mathrm{A}$ are at optimum levels

$\overline{B_{0}} \quad:$ The average $\mathrm{S} / \mathrm{N}$ ratios when the factor $\mathrm{B}$ are at optimum levels

$\overline{C_{0}} \quad:$ The average $\mathrm{S} / \mathrm{N}$ ratios when the factor $\mathrm{C}$ are at optimum levels

$\eta_{G} \quad:$ The calculated $\mathrm{S} / \mathrm{N}$ ratio for the optimum condition

$\overline{\eta_{G}} \quad:$ The average $\mathrm{S} / \mathrm{N}$ ratio for all factors

\section{Introduction}

Cooling is a significant requirement for the machining of metallic materials in order to prevent or minimize tool wear, thermal erosion, dimensional inaccuracy and surface roughness of workpieces. Turning is a leading machining application for which the cutting region can reach high temperatures, especially for the case of turning hard to machine materials made of nickelbased superalloys, titanium and composites [1,2]. To decrease the devastating effect of the high heat generated in cutting regions to cutting inserts and workpieces, different cooling technologies have been developed and used in manufacturing processes. These recent technologies can be listed as cryogenic cooling, minimum quantity lubrication (MQL), high pressure coolants, solid lubricants, gas/air-based coolants, vegetable-based cutting fluids, conventional cutting fluids and internally cooled cutting tools (ICCT). Insert tips are protected 
against failure and wear by cooling of the cutting region. Numerous cutting fluids can be used to provide quality machining performance. However, cutting fluids can cause environmental pollution and health problems for laborers. In addition, the cost of the cutting fluid can be 15$25 \%$ of the total manufacturing cost in Germany [3]. In this framework, researchers have investigated the production of different types of cutting fluids or researched the usage of some natural oils. Some studies have raised the concern of needing more natural and environmentally friendly alternatives, especially vegetable oils and biobased vegetable oils[4-9]. Biobased-type oils are generally used for MQL applications in machining. They have been used to realize some benefits such as improved machining performance, decreased machining cost and environmental friendliness. Conversely, bacterial contamination risks and poor performance under heavy machining conditions have led to biobased-type oils being considered as a less preferable choice for cutting fluids for industrial applications [4]. Some studies have focused on the use of nanofluids to provide high machining efficiency, high surface quality and good cooling-lubrication in machining applications. These types of studies have produced different types of nanofluids that are strengthened with nanoparticles such as graphene oxide and alumina $[10,11]$. In spite of the benefits for machining, cutting fluids enhanced with nanoparticles still show some doubts due to their high manufacturing cost and lack of sufficient scientific studies for direct use in manufacturing.

Recently, researchers have tended towards ICCTs because of their promising low cost, adequate environment-friendly cooling and no hazardous health effects compared to conventional cutting fluids [12-15]The general design concept for ICCTs creates a closed cooling loop in the cutting tool owing to the provision of a dry cutting process to restrict or eliminate usage of cutting fluids. Hence, there is no external cooling. When investigating studies for ICCTs, it appears that most researchers select pure water as the coolant fluid due to its superior cooling features compared to most coolant fluids for dry machining. Additionally, low cost and accessibility of pure water are significant reasons for its preference [1,16-25]. Some researchers tent towards ICCTs do not choose pure water as a coolant fluid because of the phase change temperatures. These studies claimed that internal coolant fluids are able to change the phase to transfer much more of the heat generated from the cutting contact region. As such a phase change can occur as liquid to gas during the machining, heat removal from the cutting region can be provided more effectively. They also used a condenser to turn the evaporated phase of the coolant fluid into the liquid phase in order to flood the inside of the cutting tool again. For this reason, they preferred to use R-123 (hydrochlorofluorocarbon) as a coolant fluid owing to its low boiling 
point at $28^{\circ} \mathrm{C}$ [26,27]. Nevertheless, the fluid is slightly aggressive towards condition changes and leaking problems can occur in the ICCT system. An interesting study has focused on ICCT design and manufacturing by utilizing an antifreeze (Ethylene-Glycol) used in automotive engine coolant. They reported that their design achieved acceptable and efficient cooling to qualify machining [2].

It can be claimed that the literature has still not concentrated enough on the usage of different types of heat transfer fluids used in engineering applications for use as cutting fluid in ICCTs. Heat transfer fluid selection can be a complex and multifunctional decision where parameters such as thermal conductivity, pumpability and working temperature ranges are involved. Additionally, it can affect the realization of efficient performance and economy in ICCTs. However, the selection of the right heat transfer fluid can be narrowed by determining whether or not the maximum-use temperature requirement is above approximately $175^{\circ} \mathrm{C}$ in engineering applications. If the need is above $175^{\circ} \mathrm{C}$, one can choose synthetic, organic or silicone fluids. Conversely, one needs to select inhibited glycol-based fluids, which are used for freezeprotection applications [28]. As we have observed from our previous study, the inserts can be exposed to high temperatures on their tip, but the coolant fluid cannot reach high temperatures due to the poor heat transfer capacity of the inserts [29]. For this reason, inhibited glycol-based fluids, e.g., ethylene glycol, propylene glycol and bioglycol, can be chosen for ICCT applications. The glycol-based fluids show corrosion prevention, nontoxicity and stable heat transfer features. While microbial growth is not an issue because of the biocide feature of ethylene glycol and propylene glycol, bioglycol offers its users an environmentally safer product [30].

A new internally cooled smart cutting tool (ICSCT) was designed and produced for the turning of metallic materials in our previous study. This designed ICSCT was calibrated by computational fluid dynamic (CFD) and a statistic-based method. For checking CFD simulation, an experimental setup consisting of thermocouples and a soldering machine was used [29]. After confirming the CFD simulations for pure water, the thermal behavior of the ICSCT was investigated by a CFD model under the same boundary conditions as pure water simulations according to different types of glycol-based heat transfer fluids, flow velocity $\left(\mathrm{V}_{\mathrm{f}}\right)$ and the inlet temperature of the coolant fluid ( $\left.T_{\text {inlet }}\right)$ in this study. Together with evaluating these parameters affects $\mathrm{T}_{\text {tip }}$ for insert, tool life and machining quality can increase for ICCTs in the turning applications. No external coolant was used, so the system could be counted as being environmentally friendly and health friendly even if a harmful coolant fluid was chosen as an 
internal coolant. The manufactured ICSCT has a small internal coolant volume (1.5 lt) and the internal coolant can flow in the ICSCT as closed loop. Thus, the internal coolant does not contact human or workpiece directly.

\section{Materials and Methods}

ICCTs have significant advantages such as decreased surface roughness, tool wear, and machining cost; fewer harmful effects on the environment and human health; and an increased tool life, dimensional accuracy, and machining quality. The designed and manufactured ICSCT promised some capabilities such as a decrease in the tip temperature for the insert ( $\left.\mathrm{T}_{\text {tip }}\right)$ of approximately $107^{\circ} \mathrm{C}$ and a fixing of the $\mathrm{T}_{\text {tip }}$ in a range of temperatures determined by the operator [29]. However, the thermal behavior of the ICSCT has not been compared with different types of internal coolant fluids. Thus, the comparison has been carried out with CFD simulations and the Taguchi method is discussed in this section.

\subsection{Internally Cooled Smart Cutting Tool CFD Model Design}

The CAD design for the ICSCT manufactured in our previous study is shown in Figure 1.a. The ICSCT has a self-design seat that has a special geometry to flood coolant fluid through the insert tip. After the manufacturing of the ICSCT, a conjugate heat transfer model was built by CFD, as shown in Figure 1.b. In the model, constant $T_{\text {tip }}$ values were selected for the insert tip and temperature of flank surface in insert $\left(\mathrm{T}_{\mathrm{f}}\right)$ data were predicted from the CFD model. After the derivation of the $\mathrm{T}_{\mathrm{f}}$ data, an experimental setup was constructed using a soldering iron (5 adjustable heat levels), tool holder, silicone heat transfer compound, insert, thermocouples and a holder for the soldering iron. Then, $\mathrm{T}_{\mathrm{f}}$ data were measured as corresponding to the $\mathrm{T}_{\text {tip }}$ in Celcius. Measured $\mathrm{T}_{\mathrm{f}}$ data were compared with CFD results (Figure 1.c-d). From an investigation of the $\mathrm{T}_{\mathrm{f}}$ data, it was observed that the CFD model can be used to confirm real conditions [29]. 


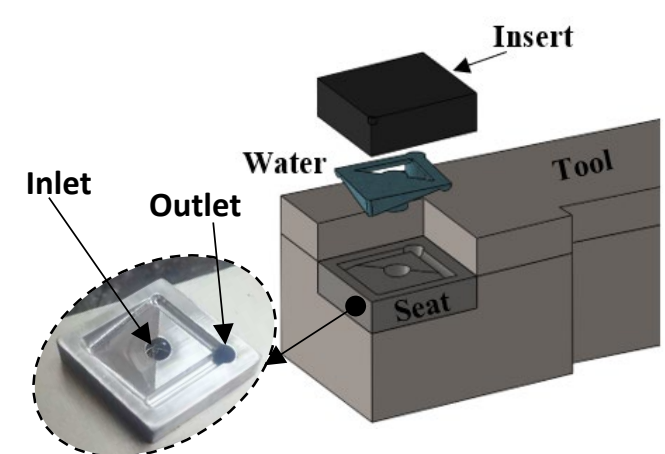

(a)

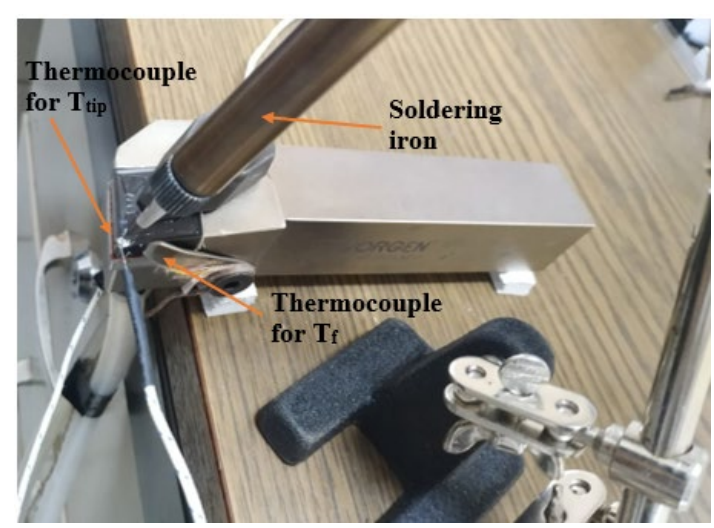

(c)

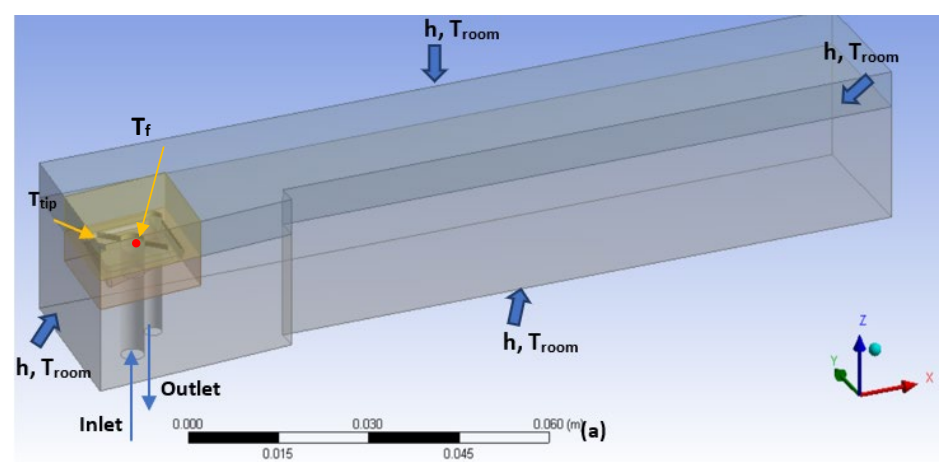

(b)

\begin{tabular}{|c|c|c|c|}
\hline \multicolumn{4}{|c|}{ Internally Cooled at $V_{f}=0.4 \mathrm{~m} / \mathrm{s}$ and $T_{\text {inlet }}=15^{\circ} \mathrm{C}$} \\
\hline & $\begin{array}{l}\mathbf{T}_{\text {tip }} \\
\left({ }^{\circ} \mathrm{C}\right)\end{array}$ & $\begin{array}{c}T_{\text {f from }} \text { CFD } \\
\left({ }^{\circ} \mathrm{C}\right)\end{array}$ & $T_{\text {f }}$ from experiments \\
\hline \multirow{5}{*}{ 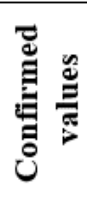 } & 25 & 16.37 & 16 \\
\hline & 37 & 17 & 17.5 \\
\hline & 55 & 17.89 & 18.25 \\
\hline & 75 & 18.9 & 19.25 \\
\hline & 93 & 19.81 & 20 \\
\hline
\end{tabular}

(d)

Figure 1. Manufactured ICSCT (a), boundary conditions of CHT Model (b), experimental setup to simulate machining process (c) and experimental confirmed data for CFD (d) [29]

A conjugate heat transfer (CHT) model, which is a CFD model, is based on the heat transfer behavior of fluid-solid contact couples. While Navier-Stokes equations are solved in the fluid domains, heat conduction equations can account for heat transfer in the solid domain. Heat transfer coefficients and temperatures at the fluid-solid interface are calculated by the local energy balance. $\mathrm{k}-\mathcal{E}$ (k-epsilon) model is the most prominent turbulence model for general purpose simulations and offers a good compromise in terms of accuracy and robustness. Also, $\mathrm{k}-\varepsilon$ turbulence model uses the scalable wall-function to make better accuracy [31]. In this study, a CHT model was selected to simulate more realistic and accurate results. The CFD simulation was set in ANSYS. The designed CHT model was set using a similar geometry, mesh type and boundary conditions as used in the previous study [29]. For clarification, the heat transfer model and boundary conditions are shown in Figure 2 and Tables 1-2. 


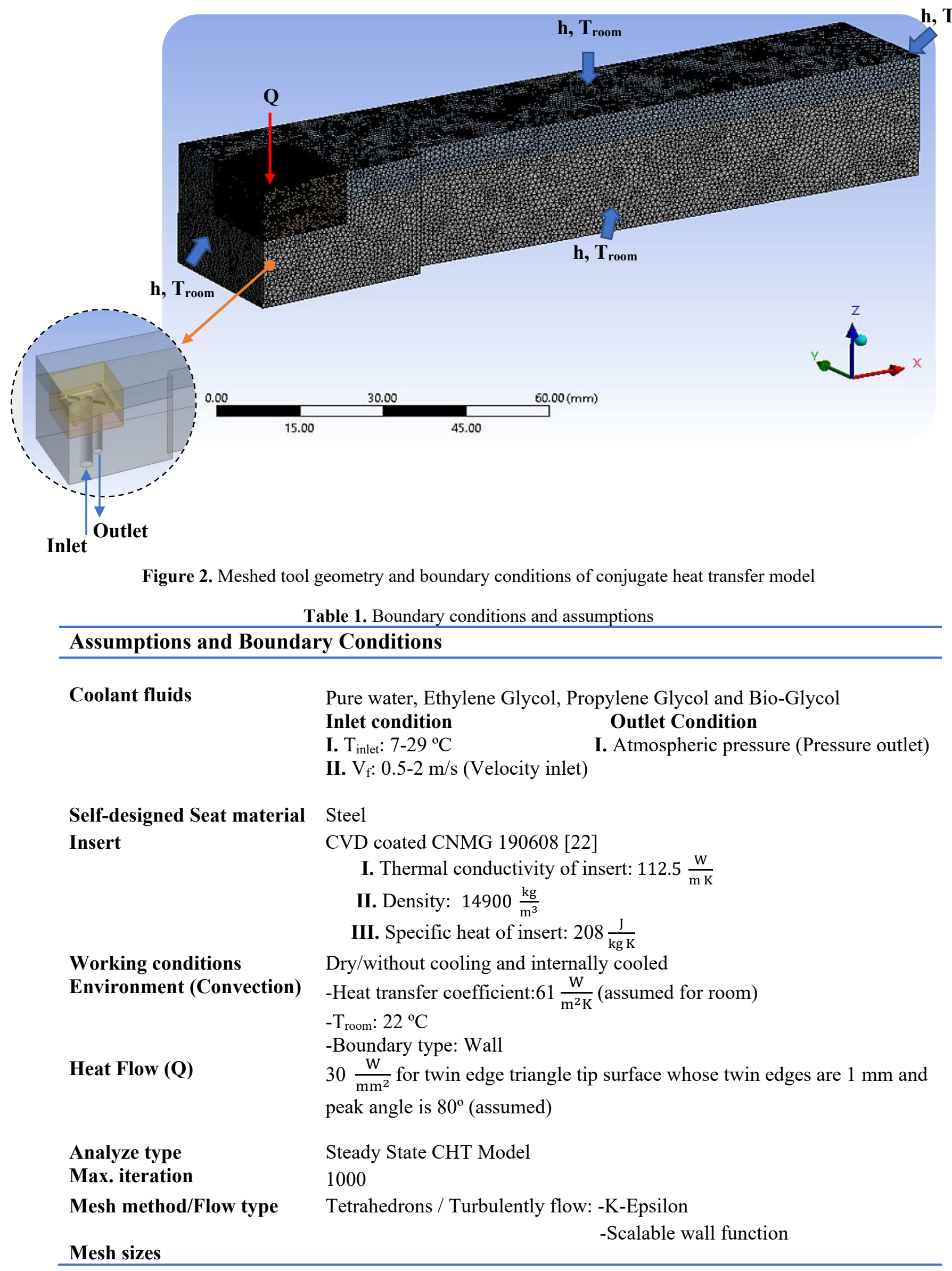


$0.2 \mathrm{~mm}$ for insert tip, $0.5 \mathrm{~mm}$ for insert, seat and water, $1 \mathrm{~mm}$ for tool holder

Heat transfer

-Total Energy for Water

Thermal energy for solid bodies

Convergence Criteria $\quad$ Residual type: Root Mean Square (RMS)

Residual target: $10^{-4}$

Table 2. Thermal Properties of the coolant fluids [30]

\begin{tabular}{|c|c|c|c|c|}
\hline & & $\% 50$ Volume & $\% 50$ Volume & \%50 Volume \\
\hline & Pure Water & Ethylene Glycol & Propylene Glycol & Bio-Glycol \\
\hline Specific Heat: & \multirow{4}{*}{$\begin{array}{l}\text { Selected from } \\
\text { Ansys database }\end{array}$} & $3248.3 \mathrm{j} / \mathrm{kgK}$ & $3532.9 \mathrm{j} / \mathrm{kgK}$ & $3549.7 \mathrm{j} / \mathrm{kgK}$ \\
\hline Viscosity: & & $0.0039 \mathrm{Ns} / \mathrm{m}^{2}$ & $0.0066 \mathrm{Ns} / \mathrm{m}^{2}$ & $0.006 \mathrm{Ns} / \mathrm{m}^{2}$ \\
\hline Density: & & $1084.93 \mathrm{~kg} / \mathrm{m}^{3}$ & $1042.85 \mathrm{~kg} / \mathrm{m}^{3}$ & $1042.85 \mathrm{~kg} / \mathrm{m}^{3}$ \\
\hline Thermal conductivity: & & $0.3799 \mathrm{~W} / \mathrm{mK}$ & $0.3626 \mathrm{~W} / \mathrm{mK}$ & $0.3626 \mathrm{~W} / \mathrm{mK}$ \\
\hline
\end{tabular}

The CFD simulations were carried out for each coolant fluid related to different $T_{\text {inlet }}$ and $V_{f}$ values under constant heat flow. The simulations were physically defined and solved. The general temperature behavior of one random simulation of pure water is given as an example in Figure 3. All simulations showed similar temperature distributions for all coolant fluids, as shown in Figure 3. The maximum temperatures were observed on the insert tip in all simulations. In addition, the fluid stream lines showed that the fluid flooded through the insert tip first and was then collected from the draining channels.

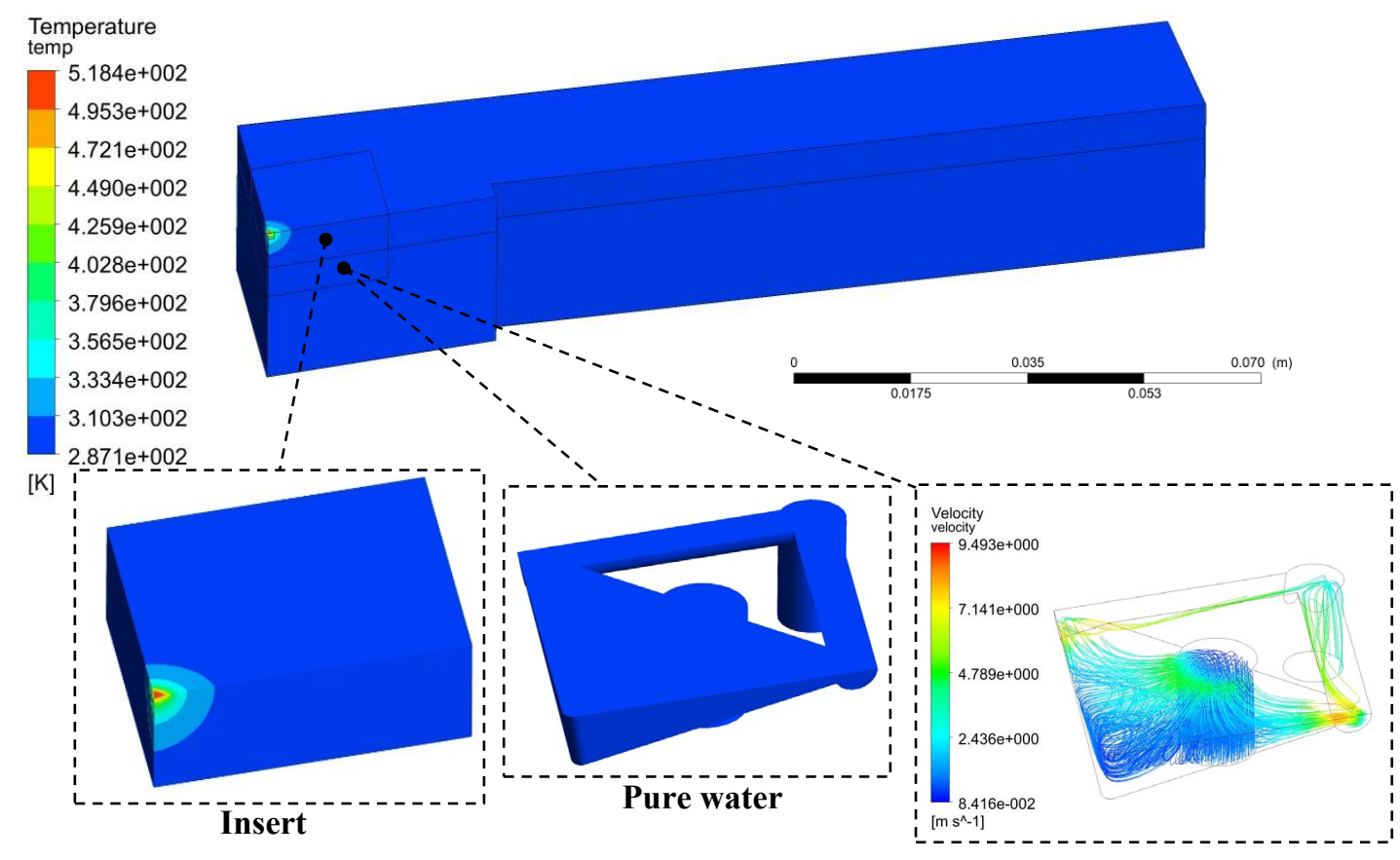

Stream lines

Figure 3. Temperature distribution for pure water at $1 \mathrm{~m} / \mathrm{s} \mathrm{V}_{\mathrm{f}}$ and $14^{\circ} \mathrm{C} \mathrm{T}_{\text {inlet }}$ 


\subsection{Design and Analysis of Simulations}

The Taguchi method is a statistical method used in the design of experiments to determine the level combinations of different factors acting on real experimental results. It is not easy to realize all experimental situations due to, e.g., the large number of experiments needed, hazardous working conditions, cost and time. The Taguchi method can be used to decrease manufacturing time, decrease costs and increase the profits of industries. In addition, real experimental conditions can be modeled and simulated by different numerical methods and Finite Element Methods (FEMs) in engineering applications. Using FEM-based simulations provides some advantages to decrease cost and time similarly. Moreover, FEM simulations create chances to limit experiments in terms of extreme values with practical constraints and to repeat the experimental results. Thus, experimentally confirmed FEM models can be used to derivate the experiment results obtained from Taguchi orthogonal arrays. In this framework, the Taguchi method and FEM were used together in different studies [32,33].

The Taguchi method transforms the experimental results to a signal-to-noise ratio $(\mathrm{S} / \mathrm{N})$. The $\mathrm{S} / \mathrm{N}$ ratio is a performance characteristic of the experimental data and is defined as the ratio of the real experiment values to the undesired random noise values [34].

Three performance characteristics can be selected in the Taguchi Method for experimental designs according to decisions made by experts. They are listed as below [35].

- Smaller is the best situations:

$$
\frac{S}{N}=-10 \log \left(\frac{1}{n} \sum_{i=1}^{n} y_{i}^{2}\right)
$$

- Higher is the best situations:

$$
\frac{S}{N}=-10 \log \left(\frac{1}{n} \sum_{i=1}^{n} \frac{1}{y_{i}{ }^{2}}\right)
$$

- Nominal is the best situations:

$$
\begin{gathered}
\frac{S}{N}=-10 \log \left(\frac{1}{n} \sum_{i=1}^{n} \frac{\bar{y}^{2}}{S^{2}}\right) \\
\bar{y}=\frac{1}{n} \sum_{i=1}^{n} y_{i}^{2}
\end{gathered}
$$




$$
S^{2}=\frac{1}{n-1} \sum_{i=1}^{n}\left(y_{i}+\bar{y}\right)^{2}
$$

where $\mathrm{y}_{\mathrm{i}}$ are the observed data in the experiments and $\mathrm{n}$ is the number of experiments for all the equations above. Additionally, $\bar{y}$ is the mean for the observed data in the experiments and $\mathrm{S}^{2}$ is the variance for the observed data in Eqs. 4-5.

In this study, different types of glycol-based heat transfer fluids, $\mathrm{V}_{\mathrm{f}}$ and $\mathrm{T}_{\text {inlet }}$ were optimized for the $\mathrm{T}_{\text {tip }}$ data derived from confirmed CFD simulations. Three factors, namely, the heat transfer fluid, $V_{\mathrm{f}}$ and $\mathrm{T}_{\text {inlet, }}$ were selected as being related to the hypothesis of "smaller is the best". The hypothesis was selected "smaller is the best" because the tip temperatures in turning process are need to be small to improve machining quality. Each factor was set in four levels for the design of the experiments. The factors and their levels are shown in Table 3. The $\mathrm{L}_{16}$ orthogonal array for the Taguchi method and the $\mathrm{S} / \mathrm{N}$ ratios calculated by using Minitab software are shown in Table 4.

Table 3. Factors and levels

\begin{tabular}{c|ccccc}
\multicolumn{1}{c}{ Factors } & Symbols & Level 1 & Level 2 & Level 3 & Level 4 \\
\hline Heat transfer Fluids & A & Pure Water & Ethylene Glycol & Propylene Glycol & Bio-Glycol \\
$\mathrm{V}_{\mathrm{f}}(\mathrm{m} / \mathrm{s})$ & $\mathrm{B}$ & 0.5 & 1 & 1.5 & 2 \\
$\mathrm{~T}_{\text {inlet }}\left({ }^{\circ} \mathrm{C}\right)$ & $\mathrm{C}$ & 7 & 14 & 21 & 29
\end{tabular}

Table 4. L16 orthogonal array, simulation results and $\mathrm{S} / \mathrm{N}$ ratios

\begin{tabular}{|cccccc|}
\hline \multicolumn{7}{c}{ Level combinations } \\
\hline Simulation no & $\mathbf{A}$ & $\mathbf{B}$ & $\mathbf{C}$ & $\mathbf{T}_{\text {tip }}\left({ }^{\circ} \mathbf{C}\right)$ & $\mathbf{S} / \mathbf{N}$ \\
\hline 1 & 1 & 1 & 1 & 241.15 & -47.6457 \\
2 & 1 & 2 & 2 & 245.25 & -47.7922 \\
3 & 1 & 3 & 3 & 250.95 & -47.9917 \\
4 & 1 & 4 & 4 & 258.05 & -48.2341 \\
5 & 2 & 1 & 2 & 253.05 & -48.0641 \\
6 & 2 & 2 & 1 & 243.75 & -47.7389 \\
7 & 2 & 3 & 4 & 261.05 & -48.3345 \\
8 & 2 & 4 & 3 & 253.25 & -48.0710 \\
\hline 9 & 3 & 1 & 3 & 259.95 & -48.2978 \\
10 & 3 & 2 & 4 & 263.15 & -48.4041 \\
11 & 3 & 3 & 1 & 243.45 & -47.7282 \\
12 & 3 & 4 & 2 & 248.25 & -47.8978 \\
13 & 4 & 1 & 4 & 265.25 & -48.4731 \\
14 & 4 & 2 & 3 & 256.55 & -48.1834 \\
15 & 4 & 3 & 2 & 249.15 & -47.9292 \\
16 & 4 & 4 & 1 & 242.35 & -47.6889 \\
\hline
\end{tabular}

\section{Simulation Results and Discussion}

The $\mathrm{S} / \mathrm{N}$ ratios for the $\mathrm{T}_{\text {tip }}$ data derived from the CFD model were calculated according to Eq. 1 using Minitab software. The main effects of the $\mathrm{S} / \mathrm{N}$ ratios for $\mathrm{T}_{\text {tip }}$ are presented in Figure 4. The optimal $\mathrm{T}_{\text {tip }}$ value will be reached at $\mathrm{A} 3 \mathrm{~B} 1 \mathrm{C} 4$, as illustrated by a red point in Figure 4. The 
optimum $\mathrm{T}_{\text {tip }}$ can be obtained from CFD simulation under $\mathrm{A} 3 \mathrm{~B} 1 \mathrm{C} 4$ conditions as $265.55{ }^{\circ} \mathrm{C}$, with an $\mathrm{S} / \mathrm{N}$ ratio calculated to be -48.48 .

\section{Main Effects Plot for SN ratios}

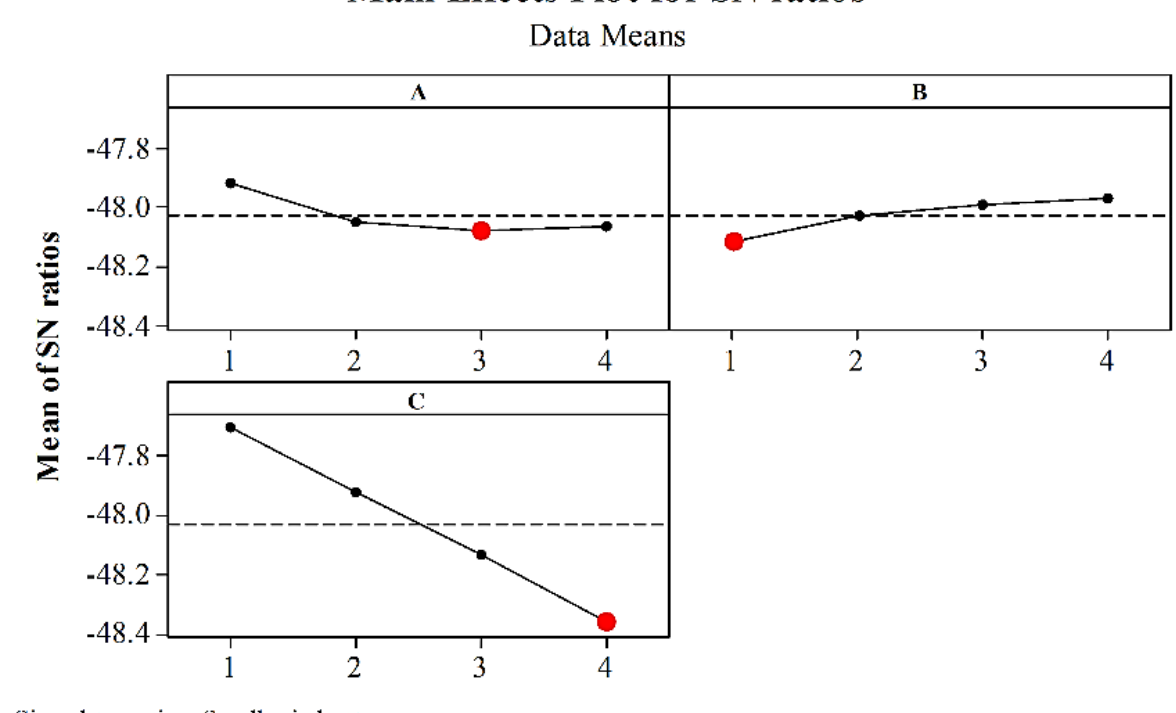

Signal-to-noise: Smaller is better

Figure 4. Main effects plot for $\mathrm{S} / \mathrm{N}$ ratios of the $\mathrm{T}_{\text {tip }}$

To analyze whether the factors have a significant influence on the simulation results, an analysis of the variance (ANOVA) can be conducted at the calculated $\mathrm{S} / \mathrm{N}$ ratios. The conducted ANOVA is presented in Table 5. Because the $p$ values were less than the reasonable alpha level $(\alpha=0.05)$, three factors had a significant effect on the simulation results. In addition, the order of effects for the factors with respect to the $\mathrm{F}$ and \% $\mathrm{PCR}$ (percentage contribution ratio) values were determined as $\mathrm{C}$ ( $\left.\mathrm{T}_{\text {inlet}}\right)$, A (heat transfer fluid type) and $\mathrm{B}\left(\mathrm{V}_{\mathrm{f}}\right)$. The main factor influencing the $\mathrm{T}_{\text {tip }}$ values for all coolant fluids was found $\mathrm{T}_{\text {inlet }}$ as 88.32 in the percentage contribution ratio. Namely, a lower $\mathrm{T}_{\text {inlet }}$ leads to a lower $\mathrm{T}_{\text {tip. }}$. Also, the heat transfer fluids and $\mathrm{V}_{\mathrm{f}}$ values influenced the $\mathrm{T}_{\text {tip }}$ values as 6.46 and $4.60 \mathrm{in} \% \mathrm{PCR}$, respectively.

Table 5. ANOVA for S/N Ratios

\begin{tabular}{c|ccccc|cc} 
Factors & DF & Seq SS & Adj SS & Adj MS & F & p & \%PCR \\
\hline A & 3 & 0.07077 & 0.07077 & 0.02359 & 20.91 & 0.001 & 6.46 \\
B & 3 & 0.05022 & 0.05022 & 0.01674 & 14.84 & 0.003 & 4.60 \\
C & 3 & 0.96648 & 0.96648 & 0.32216 & 285.53 & 0.000 & 88.32 \\
Error & 6 & 0.00677 & 0.00677 & 0.00113 & & & 0.62 \\
Total & 15 & 1.09424 & & & & & 100 \\
S $=0.0335901$ & R-Sq $=99.38 \%$ & R-Sq(adj) $=98.45 \%$ & & &
\end{tabular}

In Taguchi method, optimization is need to be verified by confirmation simulations after the determination of the optimal simulation results. If the optimum value determined with the Taguchi method was among the $\mathrm{L}_{16}$ orthogonal array, then the optimum value would not need to be confirmed. In contrast, the optimum value A3B1C4 was not between the $\mathrm{L}_{16}$, and it had 
to be confirmed using the equations given below. Thus, the optimum values for $\mathrm{T}_{\text {tip }}$ and $\mathrm{S} / \mathrm{N}$ were calculated to be $266.52^{\circ} \mathrm{C}$ and -48.51 , respectively. The calculated values were almost the same as the simulation results obtained under optimum conditions.

$$
\begin{array}{r}
\eta_{G}=\overline{\eta_{G}}+\left(\overline{A_{0}}-\overline{\eta_{G}}\right)+\left(\overline{B_{0}}-\overline{\eta_{G}}\right)+\left(\overline{C_{0}}-\overline{\eta_{G}}\right) \\
T_{t i p_{c a l}}=10^{\frac{-\eta_{G}}{20}}
\end{array}
$$

where $\eta_{G}$ is the calculated $\mathrm{S} / \mathrm{N}$ ratio for the optimum condition, $\overline{\eta_{G}}$ is the average $\mathrm{S} / \mathrm{N}$ ratio for all factors, $\overline{A_{0}}, \overline{B_{0}}$ and $\overline{C_{0}}$ are the average $\mathrm{S} / \mathrm{N}$ ratios when the factors are at optimum levels, and $T_{t i p_{c a l}}$ is the calculated $T_{\text {tip }}$ value $[34,36]$.

After statistical analysis, the effects of the heat transfer fluids and $V_{f}$ values were found to be

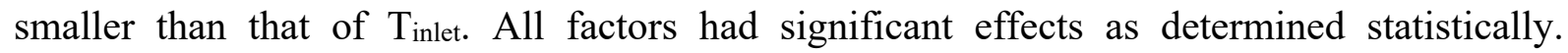
However, in order to understand whether they can affect the $\mathrm{T}_{\text {tip }}$ significantly according to the terms of engineering, the simulations were modeled at $7{ }^{\circ} \mathrm{C} T_{\text {inlet }}$ with $V_{f}$ values of $0.05 \mathrm{~m} / \mathrm{s}$ and $20 \mathrm{~m} / \mathrm{s}$ (too slow and too fast) for each heat transfer fluid (Figure 5). From a comparison of the $\mathrm{T}_{\text {tip }}$ values for the selected heat transfer fluids, pure water appeared to provide an approximately $7{ }^{\circ} \mathrm{C}$ lower temperature drop compared to the other heat transfer fluids at a $\mathrm{V}_{\text {f }}$ of $0.05 \mathrm{~m} / \mathrm{s}$. After increasing $V_{f}$ to $20 \mathrm{~m} / \mathrm{s}$, all fluids reached lower $T_{\text {tip }}$ values compared to a $V_{f}$ of $0.05 \mathrm{~m} / \mathrm{s}$. The pure water provided a $\mathrm{T}_{\text {tip }}$ that was $2{ }^{\circ} \mathrm{C}$ less than the other heat transfer fluids. This showed that a faster $\mathrm{V}_{\mathrm{f}}$ leads to lower $\mathrm{T}_{\text {tip }}$ values on the insert tip. The $2{ }^{\circ} \mathrm{C}$ temperature difference showed that all heat transfer fluids can provide a similar cooling effect on the insert tip. Additionally, all the heat transfer fluids showed similar temperature distributions in the simulations. An interesting study in the literature has claimed that for a self-designed internally cooled cutting tool, there is no cooling influence at $\mathrm{V}_{\mathrm{f}}$ values higher than $2 \mathrm{~m} / \mathrm{s}$ [21]. However, our simulations at a $\mathrm{V}_{\mathrm{f}}$ of $20 \mathrm{~m} / \mathrm{s}$ and $\mathrm{T}_{\text {inlet }}$ of $7{ }^{\circ} \mathrm{C}$ showed that $\mathrm{T}_{\text {tip }}$ can continue to drop with increasing $\mathrm{V}_{\text {f. }}$ This $\mathrm{T}_{\text {tip }}$ drop can be confirmed by the $5{ }^{\circ} \mathrm{C}$ temperature difference between the $16^{\text {th }}$ simulation in the Taguchi method and the simulation in Figure 5.h. This slight drop in temperature can be caused by geometry differences for the internal fluid flow. 


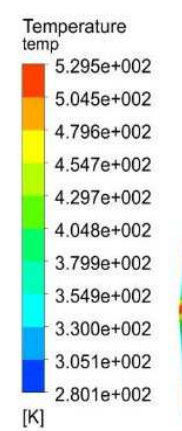

[K]

Temperature
temp

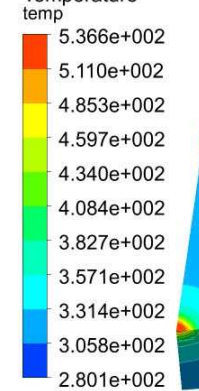

[K]

$2.801 \mathrm{e}+002$
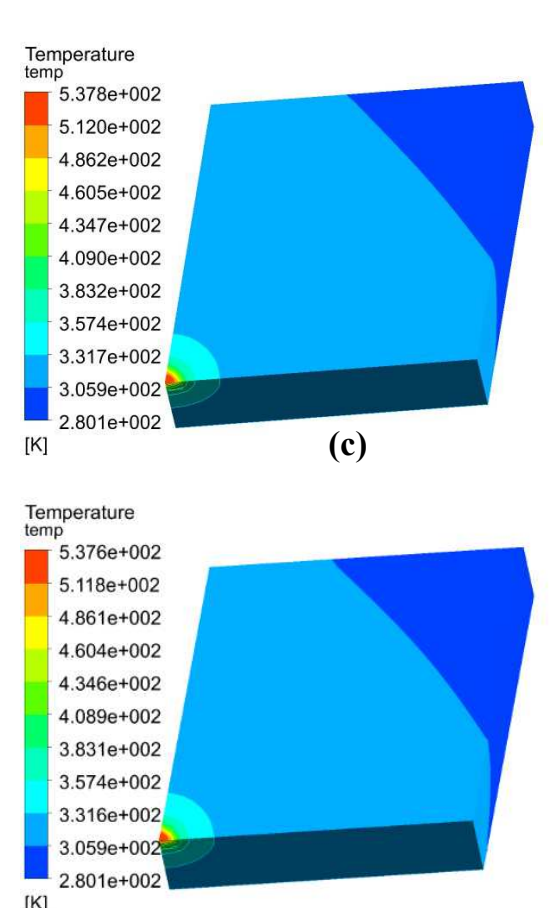

(d)

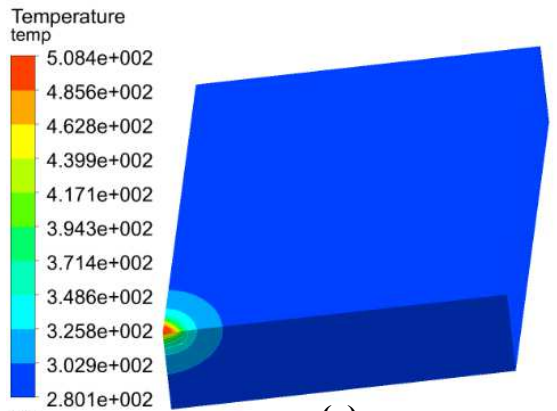

(e)

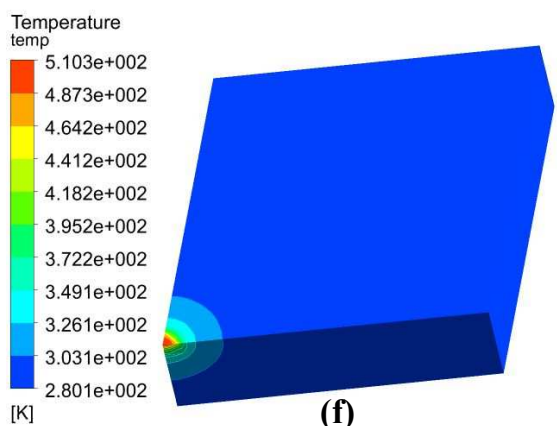

(f)

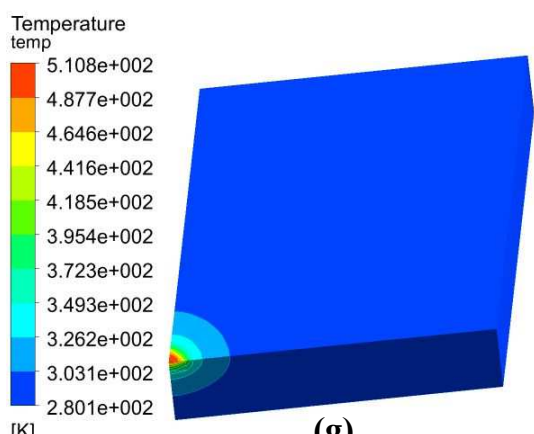

(g)

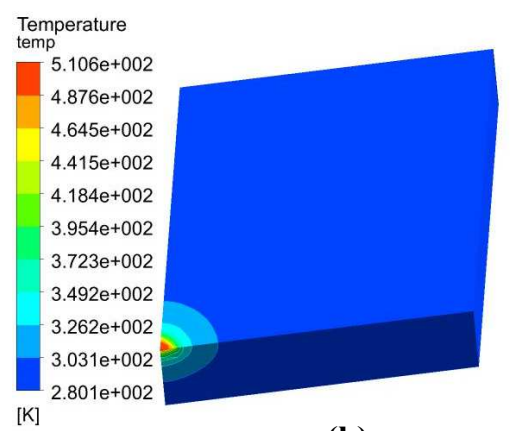

(h)

Figure 5. While the figures $a, b, c$ and $d$ show the $T_{\text {tip }}$ behaviors at $V_{f}=0.05 \mathrm{~m} / \mathrm{s}$ and $T_{\text {inlet }}=7{ }^{\circ} \mathrm{C}$ for pure water, ethylene glycol, propylene glycol and bio-glycol, respectively, the figures $\mathrm{e}, \mathrm{f}, \mathrm{g}$ and $\mathrm{h}$ show the $\mathrm{T}_{\text {tip }}$ behaviors at $V_{\mathrm{f}}=20 \mathrm{~m} / \mathrm{s}$ and $\mathrm{T}_{\text {inlet }}=7^{\circ} \mathrm{C}$ for pure water, ethylene glycol, propylene glycol and bio-glycol, respectively. 


\section{Conclusions}

In this study, the thermal behavior of a self-designed ICSCT was assessed using an experimentally confirmed CHT model for pure water. After that, the effects of different types of glycol-based heat transfer fluids, $\mathrm{V}_{\mathrm{f}}$ and $\mathrm{T}_{\text {inlet }}$ on $\mathrm{T}_{\text {tip }}$ were investigated by using the CHT model. A series of simulations were performed according to the Taguchi method, and the results are summarized below:

- The cooling effects on $\mathrm{T}_{\text {tip }}$ for four fluid types are reasonable in statistically. However, there might no significant differences found according to the terms of engineering. In other words, it was observed that $50 \%$ of the volume of the heat transfer fluids had a similar cooling capacity as that of pure water under the determined boundary conditions.

- It was observed that the $\mathrm{T}_{\text {tip }}$ values decreased for increasing $\mathrm{V}_{\mathrm{f}}$ for all coolant fluids.

- It was determined that the main factor influencing the $\mathrm{T}_{\text {tip }}$ values for all cooling fluids was $T_{\text {inlet. }}$ The percentage contribution ratio was found to be 88.32. Namely, a lower $\mathrm{T}_{\text {inlet }}$ leads to a lower $\mathrm{T}_{\text {tip. }}$. Thus, it can provide high quality machining, cost saving and delayed tool wear.

- The glycol-based fluids have some advantages compared to pure water such as corrosion prevention, nontoxicity and stable heat transfer features. Additionally, their lower temperature limits for cooling are approximately $-50{ }^{\circ} \mathrm{C}$. Therefore, glycol-based fluids can be a better choice for use in internally cooled cutting tool designs.

- While bioglycol and pure water offer users environmentally safer products directly, they can create some microbial growth problems. Conversely, microbial growth is not an issue because of the biocide feature of ethylene glycol and propylene glycol. In addition, internally cooled cutting designs have generally no need for external coolants. Thus, such systems can be counted as being environmentally friendly and health friendly even if a harmful cutting fluid is chosen as a constant small volume internal coolant.

- Glycol-based fluids can be used as a coolant at high temperature limits (up to $175^{\circ} \mathrm{C}$ ) compared to pure water. Using glycol-based fluids can be a better choice due to their upper temperature limits for the turning of difficult to machine materials, which can generate substantial heat in machining.

Next, CFD simulations and experiments for different fluid types can be compared under the same boundary conditions to improve machining quality and the tool life of the insert. 
Author Contributions: Erkan ÖZTÜRK contributed to modeling of CFD simulation and design/analysis of simulations statistically. He was the major contributor in writing manuscript. Kemal YILDIZLI suggested and commented the design of simulations and results. He was senior author and checked all the paper. Both of authors read and approved the manuscript.

Data availability: All data generated or analyzed during this study are included in the manuscript.

\section{Funding}

This study was financially supported by the Turkish Council of Higher Education under scholar grant ÖYP-1919-020.

\section{Compliance with Ethical Standards}

Competing interests: The authors declare that they have no competing interests. The manuscript is authors' original study.

Ethical approval: This study complies with the ethical standards of Springer.

Consent to participate: Not applicable.

Consent to publish: Not applicable.

\section{References}

1. Isik Y (2016) Using internally cooled cutting tools in the machining of difficult-to-cut materials based on Waspaloy. Adv Mech Eng 8 (5). doi:10.1177/1687814016647888

2. Minton T, Ghani S, Sammler F, Bateman R, Furstmann P, Roeder M (2013) Temperature of internally-cooled diamond-coated tools for dry-cutting titanium. Int J Mach Tool Manu 75:2735. doi:10.1016/j.ijmachtools.2013.08.006

3. Jen TC, Gutierrez G, Eapen S, Barber G, Zhao H, Szuba PS, Labataille J, Manjunathaiah J (2002) Investigation of heat pipe cooling in drilling applications. Part 1: preliminary numerical analysis and verification. Int J Mach Tool Manu 42 (5):643-652

4. Ali M, Azmi A, Zahiruddin M, Mohd Khalil AN, Mansor A, Salleh H (2018) The effect of concentration of coco amido propyl betaine (CAPB) as green additive in bio-based coconut oil lubricant on the machining performance of Inconel 718, vol 2030. doi:10.1063/1.5066682

5. ManojKumar K, Ghosh A (2016) Assessment of cooling-lubrication and wettability characteristics of nano-engineered sunflower oil as cutting fluid and its impact on SQCL 
grinding performance. Journal of Materials Processing Technology 237:55-64. doi:https://doi.org/10.1016/j.jmatprotec.2016.05.030

6. Radhika A, A S, B Y (2019) Evaluating machining performance of AlSI 1014 steel using gingelly oil as cutting fluid. Australian Journal of Mechanical Engineering:1-12. doi:10.1080/14484846.2019.1636517

7. Rahim E, Sasahara H (2017) Performance of palm oil as a biobased machining lubricant when drilling inconel 718. MATEC Web of Conferences 101:03015. doi:10.1051/matecconf/201710103015

8. T.P J, Sr J (2018) Performance Evaluation of Jatropha and Pongamia Oil Based Environmentally Friendly Cutting Fluids for Turning AA 6061. Advances in Tribology 2018. doi:10.1155/2018/2425619

9. Zhang J, Posinasetti N, Eckman M (2012) EXPERIMENTAL EVALUATION OF A BIOBASED CUTTING FLUID USING MULTIPLE MACHINING CHARACTERISTICS. International Journal of Modern Engineering 12:35-44

10. Li G, Yi S, Li N, Pan W, Wen C, Ding S (2019) Quantitative analysis of cooling and lubricating effects of graphene oxide nanofluids in machining titanium alloy Ti6Al4V. Journal of Materials Processing 271:584-598. doi:https://doi.org/10.1016/j.jmatprotec.2019.04.035

11. Sharma AK, Tiwari AK, Dixit AR (2018) Prediction of temperature distribution over cutting tool with alumina-MWCNT hybrid nanofluid using computational fluid dynamics (CFD) analysis. Int J Adv Manuf Tech 97 (1-4):427-439

12. Ferri C, Minton T, Ghani SB, Cheng K (2014) Internally cooled tools and cutting temperature in contamination-free machining. P I Mech Eng C-J Mec 228 (1):135-145

13. Li TJ, Wu T, Ding XH, Chen H, Wang L (2017) Design of an internally cooled turning tool based on topology optimization and CFD simulation. Int J Adv Manuf Tech 91 (1-4):13271337. doi:10.1007/s00170-016-9804-9

14. Li TJ, Wu T, Ding XH, Chen H, Wang L (2018) Experimental study on the performance of an internal cooled turning tool with topological channel. Int J Adv Manuf Tech 98 (1-4):479485. doi:10.1007/s00170-018-2278-1

15. Zakaria MS, Nordin F, Jamalludin MR, Rosli MU, Abd Rahim WMFW, Ishak MI, Khor CY (2017) Finite Element Study on the Integrity of Tool Holder with Integrated Internal Cooling Channel. Aip Conf Proc 1885. doi:10.1063/1.5002254 
16. Isik Y, Kus A, Coskun S, Ozdemir K, Cakir MC (2017) A novel approach to use internally cooled cutting tools in dry metal cutting. Indian J Eng Mater S 24 (3):239-246

17. Peng RT, Jiang HJ, Tang XZ, Huang XF, Xu Y, Hu YB (2019) Design and performance of an internal-cooling turning tool with microchannel structures. J Manuf Process 45:690-701. doi:10.1016/j.jmapro.2019.08.011

18. Rahim WMFWA, Shahrizad AFM, Khor CY, Rosli MU, Jahidi H, Ishak MI, Zakaria MS, Jamalludini MR, Nawi MAM, Shahrin S, Zainon MZ, Nik-Ghazali N (2018) Turbulent Coolant inside Cutting Tool to Control Heat Transfer During Cutting Process. Green Design and Manufacture: Advanced and Emerging Applications 2030. doi:10.1063/1.5066771

19. Ravi AM, Murigendrappa SM (2018) Experimental Study on Internal Cooling System in Hard Turning of HCWCI using CBN Tools. Advances in Mechanical Design, Materials and Manufacture 1943. doi:10.1063/1.5029629

20. Shu SR, Cheng K, Ding H, Chen SJ (2013) An Innovative Method to Measure the Cutting Temperature in Process by Using an Internally Cooled Smart Cutting Tool. J Manuf Sci E-T Asme 135 (6)

21. Shu SR, Ding H, Chen SJ, Cheng K (2012) FEM-based design and analysis of a smart cutting tool with internal cooling for cutting temperature measurement and control. Appl Mech Mater 217-219:1874-1879.

22. Shu SR, Ding H, Chen SJ, Cheng K (2014) Thermal design and analysis of an internally cooled smart cutting tool and its implementation perspectives. Mater Sci Forum 770:120-125. 23. Sun X, Bateman R, Cheng K, Ghani SC (2012) Design and analysis of an internally cooled smart cutting tool for dry cutting. P I Mech Eng B-J Eng 226 (B4):585-591

24. Wu T, Li TJ, Ding XH, Chen H, Wang L (2018) Design of a Modular Green Closed Internal Cooling Turning Tool for Applications. Int J Pr Eng Man-Gt 5 (2):211-217. doi:10.1007/s40684-018-0021-x

25. Yao B, Sun WF, Chen BQ, Yu XJ, He YC, Feng W, Wang SY (2017) An Independent Internal Cooling System for Promoting Heat Dissipation during Dry Cutting with Numerical and Experimental Verification. Appl Sci-Basel 7 (4). doi:10.3390/App7040332

26. Sanchez LEDA, Neto RRI, Fragelli RL, da Silva CE, Scalon VL (2016) Machining with internally cooled toolholder using a phase change fluid. Proc Cirp 41:847-851. doi:10.1016/j.procir.2015.12.007 
27. Vicentin GC, Sanchez LEA, Scalon VL, Abreu GGC (2011) A sustainable alternative for cooling the machining processes using a refrigerant fluid in recirculation inside the toolholder. Clean Technol Envir 13 (6):831-840. doi:10.1007/s10098-011-0359-z

28. How to Choose the Right Heat Transfer Fluid ( January 2010). Process Heating. Trademark of The Dow Chemical Company, https:/www.process-heating.com/

29. Ozturk E, Yildizli K, Saglam F (2020) Investigation on an Innovative Internally Cooled Smart Cutting Tool with the Built-in Cooling-Control System. Arab J Sci Eng

30. Dynalene Heat Transfer Fluids Technical Datasheets. https://www.dynalene.com/heattransfer-fluids/. 31.03 .2020

31. ANSYS I (November, 2011) ANSYS CFX-Solver Modeling Guide.

32. Cappetti N, Naddeo A, Naddeo F, Solitro GF (2016) Finite elements/Taguchi method based procedure for the identification of the geometrical parameters significantly affecting the biomechanical behavior of a lumbar disc. Comput Method Biomec 19 (12):1278-1285. doi:10.1080/10255842.2015.1128529

33. Chen DC, You CS, Nian FL, Guo MW (2011) Using the Taguchi Method and Finite Element Method to Analyze a Robust New Design for Titanium Alloy Prick Hole Extrusion. Procedia Engineer 10. doi:10.1016/j.proeng.2011.04.016

34. Gunay M, Yucel E (2013) Application of Taguchi method for determining optimum surface roughness in turning of high-alloy white cast iron. Measurement 46 (2):913-919. doi:10.1016/j.measurement.2012.10.013

35. Ic YT, Duran H, Kececi B, Ilik E, Bilgic B (2016) Development of a Computer Application for Multi-Response Taguchi Optimization. J Polytech 19 (3):311-323. doi:10.2339/2016.19.3 36. Gologlu C, Sakarya N (2008) The effects of cutter path strategies on surface roughness of pocket milling of 1.2738 steel based on Taguchi method. Journal of Materials Processing Technology 206 (1-3):7-15. doi:10.1016/j.jmatprotec.2007.11.300 


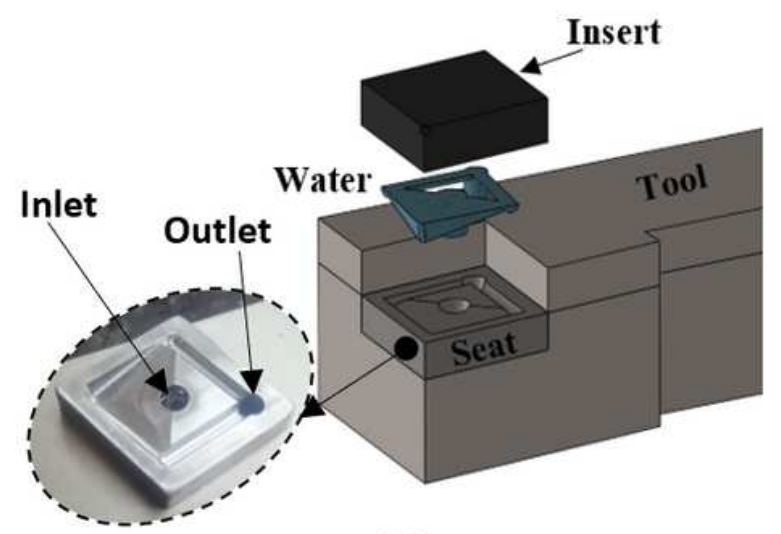

(a)

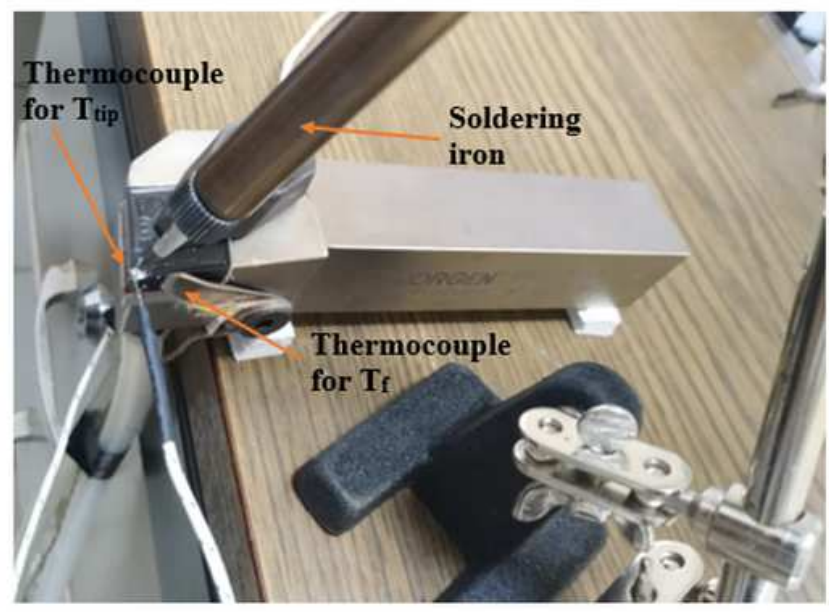

(c)

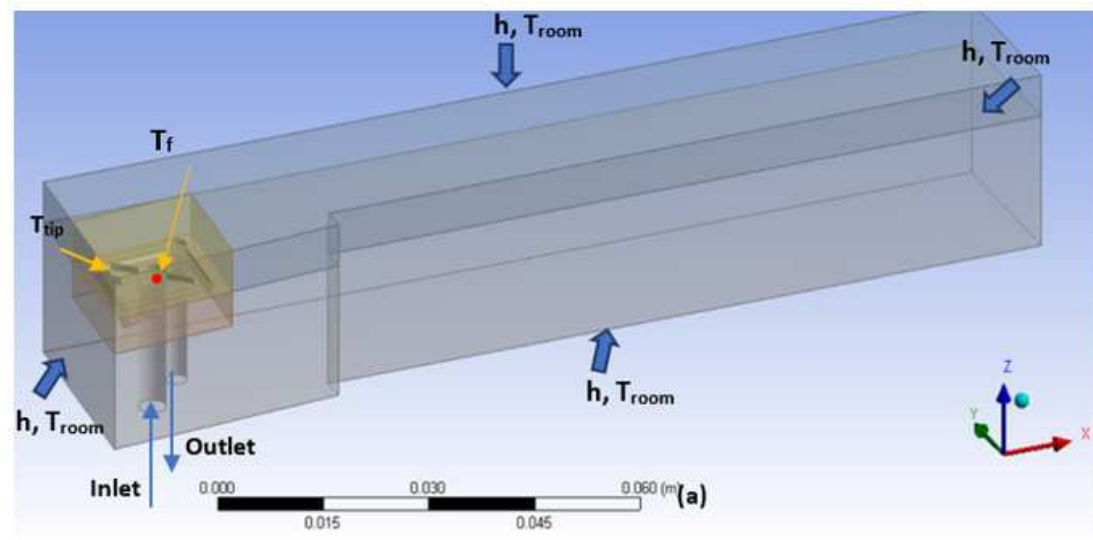

(b)

\begin{tabular}{|c|c|c|c|}
\hline \multicolumn{4}{|c|}{ Internally Cooled at $\mathrm{V}_{\mathrm{f}}=\mathbf{0 . 4} \mathrm{m} / \mathrm{s}$ and $\mathrm{T}_{\text {inlet }}=15^{\circ} \mathrm{C}$} \\
\hline \multirow{2}{*}{} & $\begin{array}{c}\mathrm{T}_{\text {tip }} \\
\left({ }^{\circ} \mathrm{C}\right)\end{array}$ & $\begin{array}{c}\mathrm{T}_{\mathrm{f}} \text { from CFD } \\
\left({ }^{\circ} \mathrm{C}\right)\end{array}$ & $\begin{array}{c}\mathrm{T}_{\mathrm{f}} \text { from experiments } \\
\left({ }^{\circ} \mathrm{C}\right)\end{array}$ \\
\hline \multirow{3}{*}{} & 25 & 16.37 & 16 \\
\cline { 2 - 4 } & 37 & 17 & 17.5 \\
\cline { 2 - 4 } & 55 & 17.89 & 18.25 \\
\cline { 2 - 4 } & 75 & 18.9 & 19.25 \\
\cline { 2 - 4 } & 93 & 19.81 & 20 \\
\hline
\end{tabular}

(d)

Figure 1

Manufactured ICSCT (a), boundary conditions of CHT Model (b), experimental setup to simulate machining process (c) and experimental confirmed data for CFD (d) [29] 


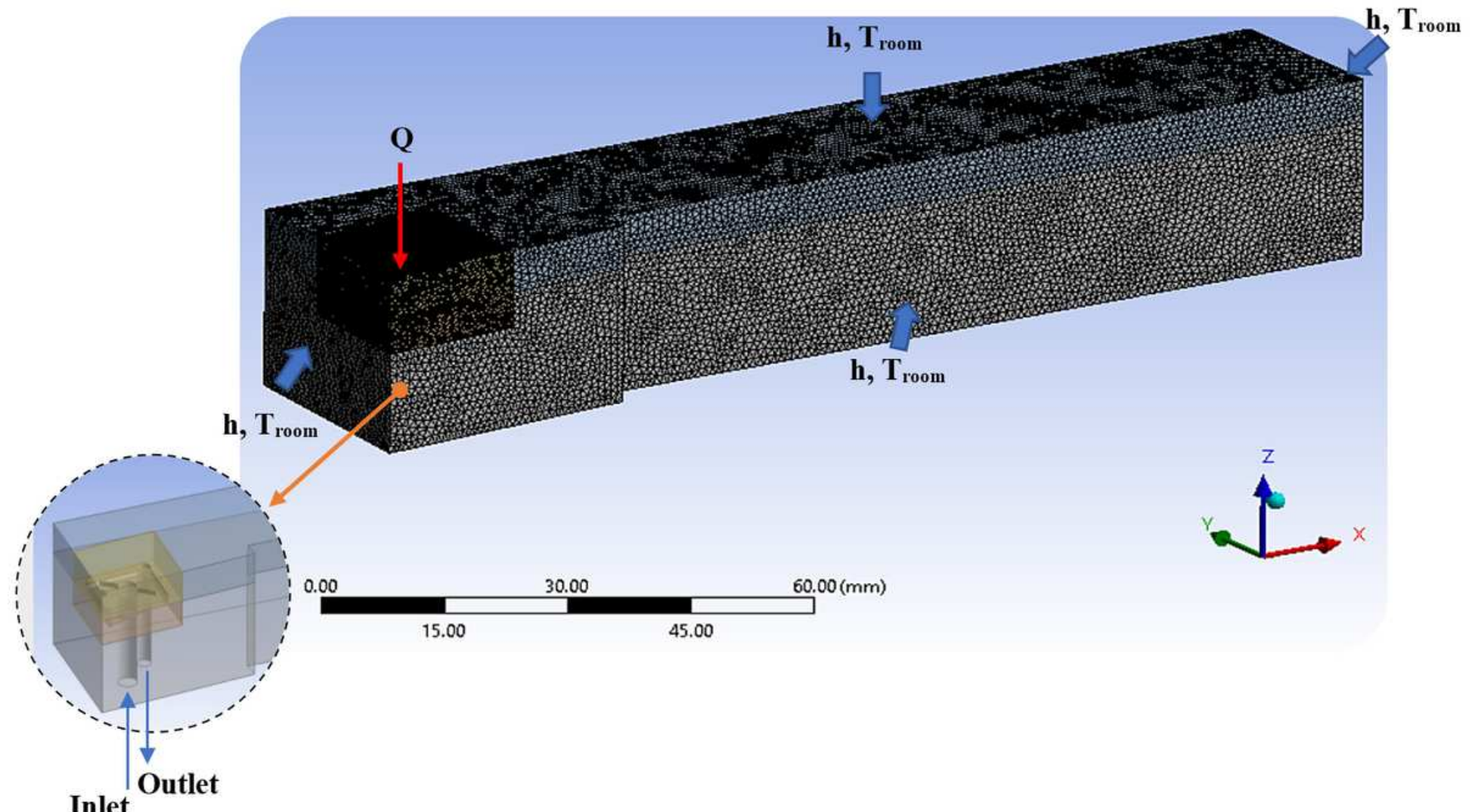

Figure 2

Meshed tool geometry and boundary conditions of conjugate heat transfer model 


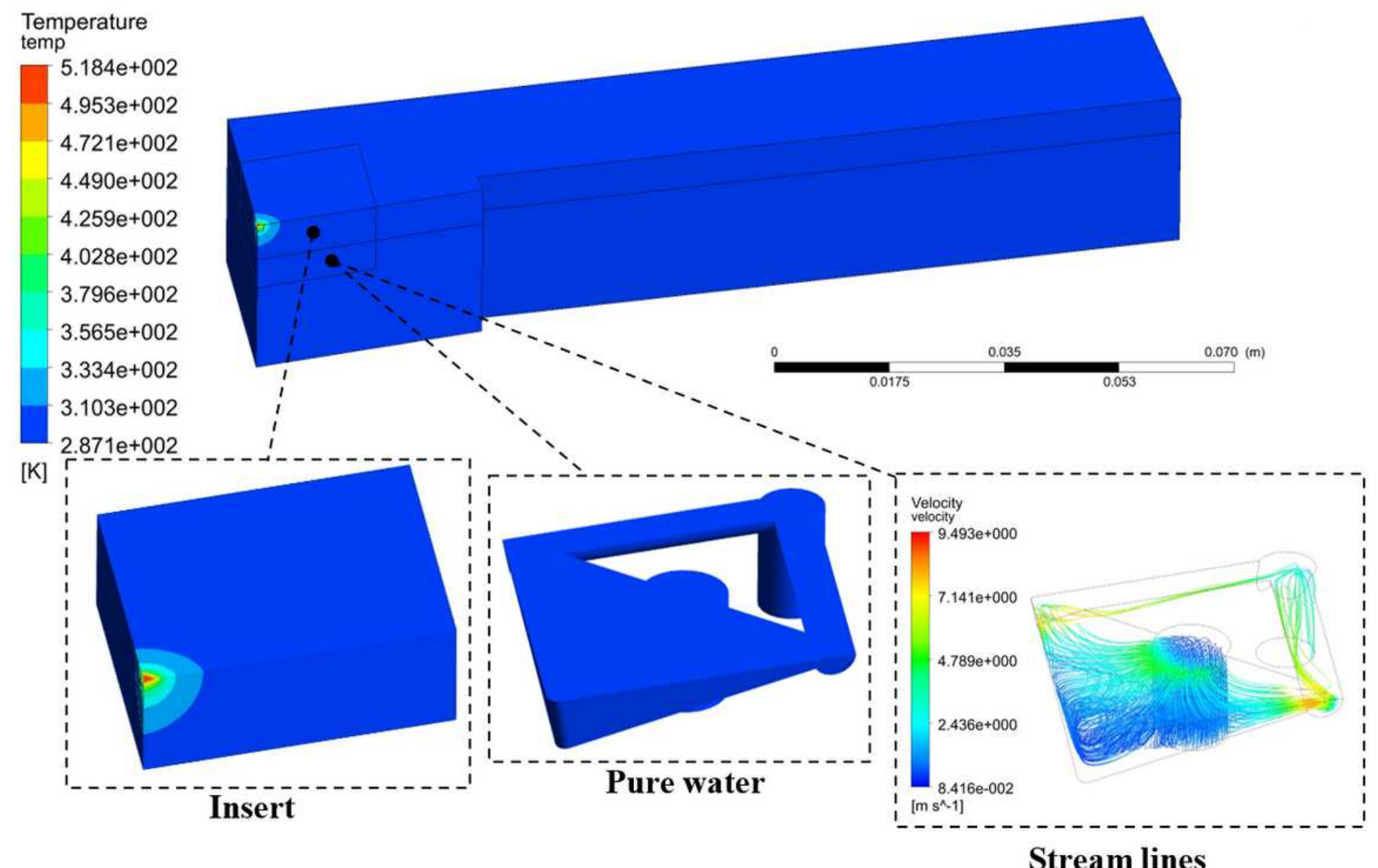

Figure 3

Temperature distribution for pure water at $1 \mathrm{~m} / \mathrm{s} \mathrm{Vf}$ and $14{ }^{\circ} \mathrm{C}$ Tinlet 


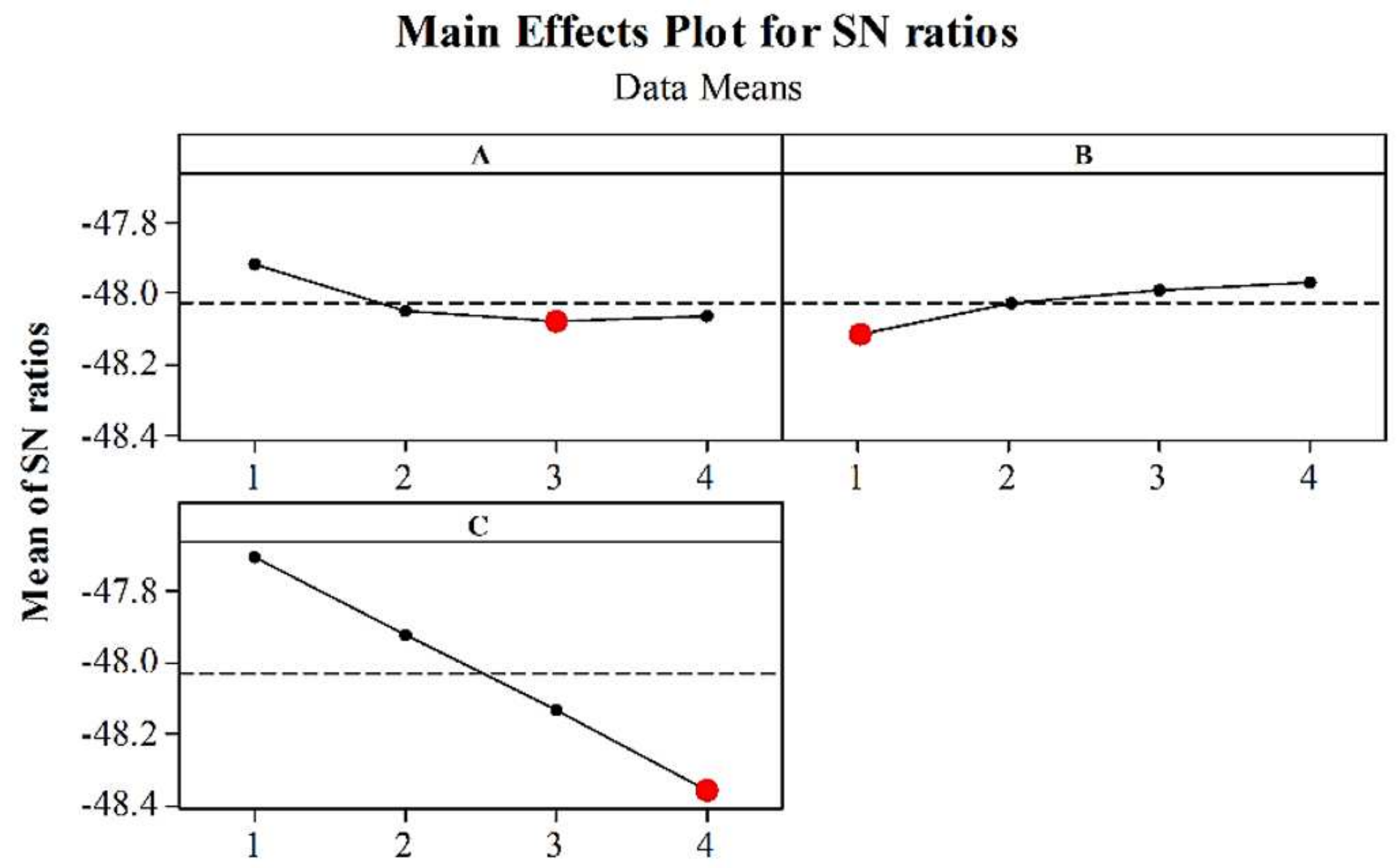

Signal-to-noise: Smaller is better

Figure 4

Main effects plot for $\mathrm{S} / \mathrm{N}$ ratios of the Ttip 


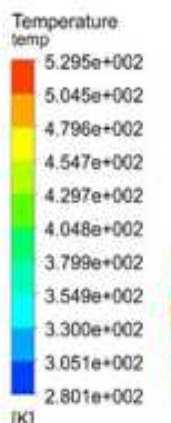

[K]

Temperature temp

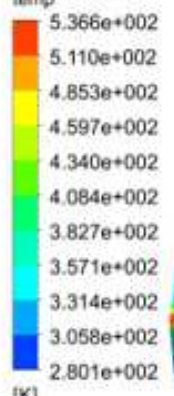
[K]

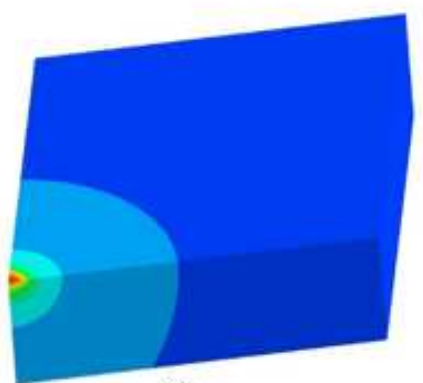

(a)

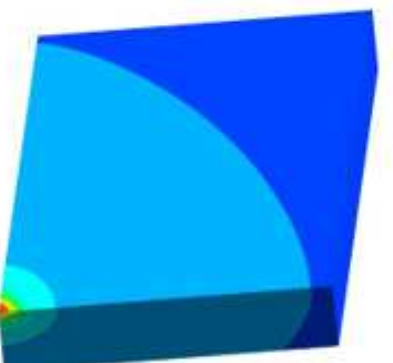

(b)
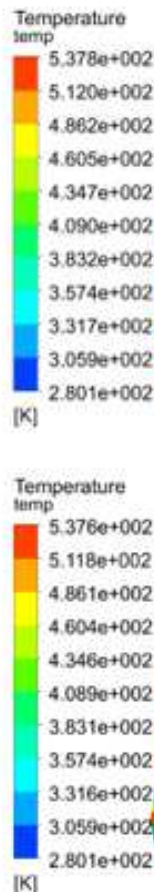

[K]

(c)
Temperature

$5.084 \mathrm{e}+002$

$4.856 \mathrm{e}+002$

$4.628 \mathrm{e}+002$

4. $3990+002$

4. $171 \mathrm{e}+002$

$3.943 \mathrm{e}+002$

$3.714 \mathrm{e}+002$

$3.486 \mathrm{e}+002$

$3.258 \mathrm{e}+002$

$3.029 \mathrm{e}+002$

$2.801 e+002$

[K]

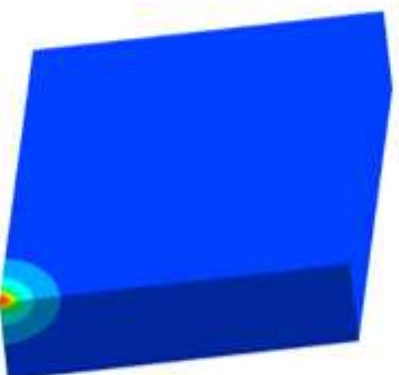

(e)

Temperature

temp $5,103 e+002$

$4.873 e+002$

$4.642 \mathrm{e}+002$

$4.412 \mathrm{e}+002$

$4.182 \theta+002$

$3.952 \theta+002$

$3.722 \theta+002$

$3.491 \mathrm{e}+002$

$3.261 \mathrm{e}+002$

$3.031 \mathrm{e}+002$

$2.801 e+002$

[K]

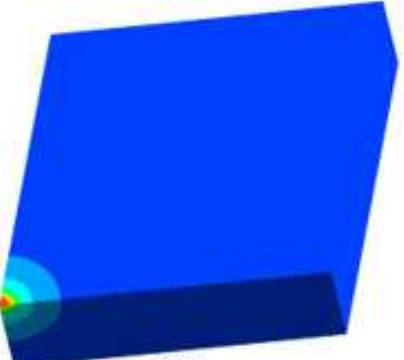

(f)

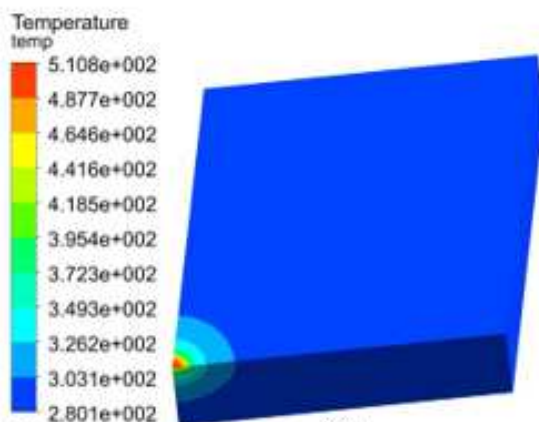

(g)

[K]

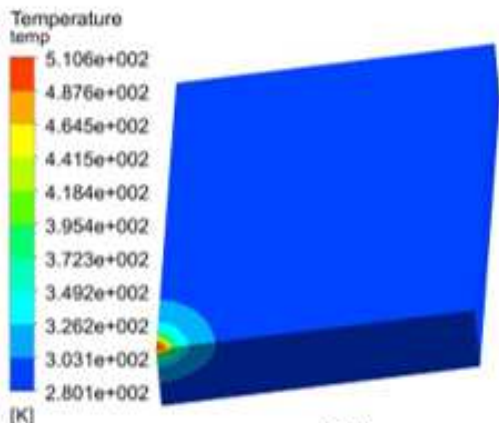

(h)

(d)

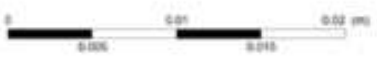

\section{Figure 5}

While the figures $a, b, c$ and $d$ show the Ttip behaviors at $\mathrm{Vf}=0.05 \mathrm{~m} / \mathrm{s}$ and Tinlet $=7^{\circ} \mathrm{C}$ for pure water, ethylene glycol, propylene glycol and bio-glycol, respectively, the figures e, $\mathrm{f}, \mathrm{g}$ and $\mathrm{h}$ show the Ttip behaviors at $\mathrm{Vf}=20 \mathrm{~m} / \mathrm{s}$ and Tinlet $=7^{\circ} \mathrm{C}$ for pure water, ethylene glycol, propylene glycol and bio-glycol, respectively. 


\section{Supplementary Files}

This is a list of supplementary files associated with this preprint. Click to download.

- Highlights.docx 